\title{
Pedagógus, bátran menj oda, AHOVÁ EMBER MÉG NEM MERÉSZKEDETT!
}

\author{
FRÁNYÓ ZSÓFIA
}

PhD-hallgató, ELTE PPK Neveléstudományi Doktori Iskola

Gretchen M. Reevy \& Stanley N. Bursten: Pedagogical psychology: beyond the 21st century. 2015. Frontiers in Psychology, 2015. 80 p. ISSN: 1664-1078, ISBN: 9782-88919-562-6

A Frontiers in Psychology által 2015-ben megjelentetett tanulmánykötet (a folyóirat tematikus különszáma) a jövő (feltételezett) pedagógiai pszichológiájáról szól. A szerkesztők nem egy átfogó munkát kínálnak az olvasónak, célul azt tüzték ki, hogy rövid bepillantást nyújtsanak azokba a változásokba, amelyek az oktatás világában is egyre gyorsuló ütemben zajlanak. A 20. században az elmélet és a kutatás általában a hagyományos tanulási modellt követte (a legfontosabb pedagógiai módszer az előadás: a tanár aktív, a diák passzív befogadó), azonban a tanulók rendkívül változatos összetétele, a sokszínü igények megjelenése, az elektronikus adatmegosztás (internet) és a globális kooperáció/versengés kora új megközelítéseket hoz magával. Régi modelleket cserélnek le olyanokra, melyek többek között a technológiában végbemenő változásokat is kihasználják, és a pedagógiát egy eddig talán soha nem látott pályára terelik. A ma még mindig sokak által elképzelhetetlennek tűnő változások már a jelen kutatások részét képezik. A kötetbe válogatott tanulmányok kimondott célja, hogy a teljesség igénye nélkül, intuitív módon, mégis realisztikusan érzékeltessék a pedagógiai pszichológia és az oktatás jövőjének trendjeit. $\mathrm{E}$ célból a kötet szerkesztői több, egymástól fajsúlyukban is eltérő cikket válogattak össze, így teljesen szubjektív véleménycikkek mellett több évig tartó kutatást lezáró tanulmányokat is olvashatunk. Úgy vélem, éppen ez a sokszínűség biztosítja az olvasó számára azt az izgalmat, amit minden jövőbe tekintő felfedező érezhet, mielőtt belépne az időgépbe.

A kötet első három írása - Intelligens Virtuális Ágens (IVA), Virtuális Valóság (VR), illetve a gesztus (testbeszéd) szerepe az idegen nyelv oktatásában - egy téma köré épül. Manuela Macedonia, Iris Groher és Friedrich Roithmay Intelligent virtual agents as language trainers facilitate multilingualism címü munkájában megismerkedhetünk Billie-vel, „aki” virtuális személyként humán tanárhoz hasonlatosan oktat gyerekeket és felnőtteket egyaránt az idegen (vagy második) nyelv szavaira. A cikk bemutatja az IVA alkalmazásának aktuális eredményeit, előnyeit és jövőbeli lehetőségeit. Billie jelen pillanatban föként szótanításra alkalmas eszköz, mely AsapRealizer rendszer alapján nonverbális jelölőnyelvet (Behaviour Markup Language - BML) használva koordinálja a beszédet, a gesztusokat, a test és fej mozgását, aminek köszönhetően egy kisfiúhoz hasonló viselkedéssel lép kapcsolatba a tanulókkal. Azonban Billie az idegtudo- 
mány legújabb eredményeit is felhasználja a tanításban: a szó kimondásával egy időben egy, a szót jellemző, ikonikus kézmozdulatot is végez annak érdekében, hogy a szó jobban bevésődjön a memóriába, nehezebben kopjon ki onnan.

A z ún. enactment hatásról, amely szerint a kézmozdulatok segítik a kognitív folyamatokat, már sok tanulmány született, azonban a testet a mai napig nem tekintik tanulási eszköznek, holott laboratóriumi vizsgálatok egyértelműen bizonyítják, hogy a cselekvés melletti tanulás kiterjesztett memóriahálózatot hoz létre a nyelvért felelős agyterületeken, mivel a szenzomotoros és asszociációért felelős területek is bekapcsolódnak a folyamatba. A megnövekedett ideghálózat miatt a rövid és hosszú távú memória javul a hagyományos audiovizuális tanulási módszerhez képest.

Manuela Macedonia IVA-val folytatott kutatásai arra a következtetésre jutnak, hogy Billie tevékenysége bizonyos (a cikkben közölt) feltételek mellett jobb eredményeket produkál, mint a kísérletben részt vevő tanár (ember). Ez számos következtetésre ad lehetőséget, hiszen míg egy emberi tanár reprodukálhatatlan tulajdonságai ellenére bizonyos szinten túl már csak minimális fejlődésre képes, addig a technológia adta lehetőségek messzire mutatnak. Billie egy megfelelő humán forrású beszédadatbázisból táplálkozó fejlett automata beszédfelismerő (ASR) szoftver segítségével már korrektív feedback funkcióval is rendelkezhet, melynek segítségével kijavíthatja, korrigálhatja a tanulót.

Billienek további előnyei is vannak: nem fárad el, és csak pozitív motivációt ad a tanulónak. Megfelelő adatbázissal a háttérben nem csupán egy szabvány oktatási tervet hajt végre, de alkalmazkodhat a tanuló szociális helyzetéhez, értelmi, tanulási képességeihez, felmérheti speciális igényeit, és személyre szabott tanulási programot konstruálhat számára, nem is beszélve arról a nem elhanyagolható tényről, hogy Billie időtől és helytől függetlenül bármikor elérhető, és szolgálatai nagyságrendekkel megfizethetőbbek, mint humán versenytársainak a munkája.

A témát kiegészítő további két cikkben Claudia Repetto a Virtuális Valóság szerepét tárgyalja a tanulási folyamatokban (The use of virtual reality for language investigation and learning), Manuela Macedonia pedig a testbeszéddel rásegített nyelvtanulás lehetséges szerepét vizsgálja (Bringing back the body into the mind: Gestures enbance word learning in foreign language). Az általuk felsorakoztatott $\mathrm{ku}$ tatási eredmények ígéretesek: a test taneszközként való alkalmazása alapvető fontosságúvá válhat a közeljövőben.

Ezt követően, mintegy intermezzóként, egy rövid írás következik, amely egy szokatlan, de hatékony módszert mutat be a tudományos gondolkodás elősegítésére. Rodney Schmaltz és Scott O. Lilienfeld tanulmányából (Hauntings, homeopatby, and the Hopkinsville Goblins: Using pseudoscience to teach scientific thinking) a pszeudotudományok tudományos alkalmazását ismerhetjük meg. Az írás számos érzékletes példával illusztrálja, hogy az áltudományos állítások (pl. vonzás törvénye, homeopátia, kanálhajlítás) és a tudományos állítások ütköztetése hogyan növeli a hallgatók tudományos érvelési képességeit, miként nevel egy - nem csak - tudósként követendő tudományos szkepticizmusra.

Ezután a „Frontier-időgép” közelebb kerül a jelenhez. Nava Levit Binnun és Ricardo Tarrasch egy több hónapig végzett kutatás eredményeiről számol be (Relation between contemplative exercises and an enriched psychology students' experience in a neuroscience course), ezzel szélesítve a jövőben oktatási eszközként használható új megközelítések és módszerek tárházát. A kutatás arra próbált választ találni, hogy a pszichológiahallgatók idegtudományi 
kurzusain bevezetett buddhista gyökerü kontemplációs gyakorlatok miként segítik elő az anyag megértését, a tanórai figyelem koncentrációját. A cikk érdekessége nem csupán a kiterjedt vizsgálati eredményekben összegezhető, hanem abban is, hogy a felsőoktatás berkein belül egyre nagyobb az érdeklődés a tudásmegszerzés alternatív módszerei iránt. Ennek egy példáját mutatja be az írás: pszichológus hallgatók új módon, saját maguk által és magukban (magukon) végzett kísérletek (kontemplációs technikák) segítségével próbálnak megérteni nem feltétlen magától értetődő, sőt egyenesen nehezen befogadható idegtudományi fogalmakat.

A kötet olvasója persze itt is felfigyelhet arra a jelenségre, hogy a jövő esetleges oktatási módszereiben minduntalan felmerül egy visszatérő motívum: mégpedig az a tendencia, hogy a tudás megszerzésének módjai a kognitív folyamatok egyre komplexebb, integráltabb egységét képezik, ahol a személyes tapasztalás, az információ megszerzése már nem az egydimenziósnak ható audiovizuális sémát követi, hanem egyszerre „több oldalról” teszi lehetővé és segíti elő a megértést. Az új technológiák (VR, IVA) és a régről ránk hagyományozódott, de eddig nem kihasznált módszerek (kontemplációs gyakorlatok) mind ezt a célt szolgálják.

Ha az olvasó áttekinti az eddig ismertetett tanulmányok sorrendjét, már biztosan érzi a tendenciát, ahogy a Billie által fémjelzett messzi jövőből egyre inkább közelítünk a jelen felé. Nem csoda, hogy a következő két cikk a jelen oktatási gyakorlatnak már integráns részét képező online oktatás kérdéseit tárgyalja.

Morton Ann Gernsbacher tanulmányában (Why internet-based education?) mosolyogtató lelkesedéssel sorolja fel az online képzések előnyeit és jövőbe mutató pozitív hatásait. Ecseteli a hely- és időfüggetlen tudásanyag-elérés tanulókra gyakorolt jó- tékony hatását. Azt, hogy az online kurzusok lehetővé teszik a személyes tanulási igények kielégítését, mélyítik a memóriát, erősítik a kritikai gondolkodást és növelik az írásképességet. Nem lebecsülve a cikkíró odaadását, halkan megjegyzem, hogy valószínüleg a jövő sem lesz tökéletesen fényes, mindig maradnak "sötét” foltok. Mindazonáltal a cikk éppen megfelelő arra, hogy az oktatástudomány előremutató lelkes törekvéseinek hangot adjon.

Ezt a talán túlzottan pozitív felhangú cikket állítja Föld körüli pályára Judy R. Van Dóron és John D. Van Doorn szerzőpáros írása (The quest for knowledge transfer efficacy: Blended teaching, online and in-class, with consideration of learning typologies for non-traditional and traditional students). Céljuk az volt, hogy számos kutatási anyag eredményeit felhasználva olyan tipológiát hozzanak létre, mely jól jellemzi a hagyományos (tanuló és nem dolgozó fiatal) és nem hagyományos (rész- vagy fóállásban dolgozó, sokszor családos, többnyire idősebb) diákok tanulási stílusát és tanulási szükségleteit. Az így kialakított tanulásiszükséglet-tipológia segítségével és a hagyományos és nem-hagyományos szükségletek összehasonlító elemzésével, illetve a tantervek figyelembevételével átfogalmazhatókká válnak a különböző oktatási formák (kevert, online, osztálytermi) és azok rendelkezésre bocsátásának módjai. A tanulmány egyik konkrét eredménye (nem számítva az elemzés egyéb, adatokkal nem kellően alátámasztott, de érdekfeszítő állításait) annak megállapítása, hogy a különböző oktatási formák közül a nem tradicionális hallgatók számára a kevert (blended) oktatás a legmegfelelőbb, mely egyaránt tartalmaz online feladatokat, valós idejü és késleltetett online kurzusokat, osztálytermi módszereket.

A cikk elolvasása után ismét egy visszatérő motívumra figyelhetünk fel: a tanár technikai, módszertani képességeinek, fel- 
készültségének rendkívüli fontosságára és a tanárok folyamatos képzésének elengedhetetlen voltára. Ide sorolható a következő két cikk is. Az elsőben Rodney M. Schmaltz és Rickard Enström a PowerPoint prezentációk csapdáira hívja fel a figyelmet (Death to weak PowerPoint: Strategies to create effective visual presentations), a másodikban $\mathrm{Kim} \mathrm{J}$. Calder Stegemann személyes vallomását olvashatjuk, aki azt meséli el, hogy miként tette „21.-század-kompatibilissé” oktatáspszichológiai bevezető kurzusát (Confessions of an educational psychologist). A két írás rövid és inkább anekdotikus jellegü, de mindkettő felhívja a figyelmet arra, hogy a modern oktatásban nem elhanyagolható szempont a hallgatók figyelmének lekötése, a tudásmegszerzés változásainak figyelembevétele, a meglévő anyagok folyamatos átgondolása és modernizálása.

Végül - időgéphasonlatunk záróakkordjaként - a szemelvénykötet utolsó tanulmánya visszahoz bennünket a jelenbe. Gretchen M. Reevy és Grace Deason a nontenure oktatói státusszal járó káros hatásokkal foglalkozik (Predictors of depression, stress, and anxiety among non-tenure track faculty). A téma talán földhözragadtnak tünik, de ha figyelembe vesszük, hogy a kérdést eddig még jóformán senki sem kutatta, azt is mondhatjuk, hogy ez a cikk is a jövőbe mutat, hiszen olyan kérdést tárgyal, mely közvetlen hatással van és lesz a felsőfokú oktatási intézményekre. Az Egyesült Államok tanári státuszainak 70 százaléka non-tenure pozíció (határozott idejü szerződéses foglalkoztatás, ahol a szerződést jó esetben újra és újra megújítják). Az ismertetett kutatás elött nem folytattak olyan vizsgálatot, amely számba vette volna azon faktorokat, melyek segítségével előre jelezhetők a tanárokat érő egészségkárosító, negatív hatások és a nyomukban kialakuló depresszió, stressz, szorongás.

A vizsgálat előzetes, más területen végzett kutatási eredményekre és saját - kvantitatív és kvalitatív - felmérésre támaszkodva érdekes eredményeket hozott. Kimutatta, hogy a stressz, szorongás, depresszió milyen összefüggésben áll a non-tenure oktatók demográfiai helyzetével (pl. családi jövedelem), megküzdési mechanizmusával (coping mechanisms), illetve szervezeti elkötelezettségével. A kutatás egyik érdekes eredménye az, hogy a non-tenure oktató szervezet felé mutatott elkötelezettsége a más vizsgálati területeken tapasztaltakkal ellentétben nemhogy csökkenti, de egyenesen növeli a stresszorok jelenlétét. A cikk írói végül olyan stratégiákat is bemutatnak, melyek alkalmazásával az egyetemek könynyíthetnek a non-tenure oktatókra nehezedő nyomáson.

Amikor az olvasó „digitálisan becsukja” a szemelvénykötetet, joggal érezheti, hogy nem kapott teljes képet az oktatáspszichológia jövőjéről, apró villanásokat érzékelhetett csupán. Azonban talán éppen ez a lényeg: a kötet célja nem volt más, mint megmutatni azt, hogy a jelen jövőre irányuló vizsgálódásai, a most még csíraként jelen lévő, de rohamosan fejlődő technológiák milyen pályákat járhatnak (és valószínúleg járnak majd) be, és mivé változtathatják az oktatást. Persze nem szabad elfelejtenünk, hogy nem látunk a jövőbe: ha egy negyven évvel ezelőtt keletkezett hasonló tárgyú szemelvénykötetet vennénk most a kezünkbe, valószínűleg megrökönyödnénk azon, hogy az akkor felvázolt trendeket milyen mértékben haladtuk meg, illetve tértünk el azoktól. Ettől függetlenül kicsit mindig érdemes a jövő felé kacsintani.

A cikk a Creative Commons Attribution 4.0 International License (https://creativecommons.org/licenses/ by-nc/4.0/) feltételei szerint publikált Open Access közlemény, melynek szellemében a cikk bármilyen médiumban szabadon felhasználható, megosztható és újraközölhető, feltéve, hogy az eredeti szerző és a közlés helye, illetve a CC License linkje és az esetlegesen végrehajtott módosítások feltüntetésre kerülnek. 